\title{
PENGARUH SOSIAL EKONOMI DAN PERAN KELUARGA TERHADAP PERILAKU SEKSUAL REMAJA DI SMA KESATRIAN 1 KOTA SEMARANG
}

\author{
Lucky Indri Yania*); Friska Realita ${ }^{\text {b }}$ Endang Suranic \\ a, b,c Fakultas Kedokteran Prodi Kebidanan; Universitas Islam Sultan Agung Semarang \\ Jalan Raya Kaligawe Km. 4 Po.Box 1054/SM Semarang 50112 - Indonesia
}

\begin{abstract}
Abstrak
Kasus kehamilan tidak diinginkan (KTD) pada remaja yang terjadi akibat perilaku seksual pranikah tahun 2018-2019 sebanyak 91 kasus untuk wilayah Kota Semarang. Faktor Sosial Ekonomi dan Peran Keluarga mempengaruhi perilaku seksual remaja. Tujuan penelitian ini adalah untuk mengetahui pengaruh sosial ekonomi dan peran keluarga terhadap perilaku seksual remaja di SMA Kesatrian I Kota Semarang. Jenis penelitian ini adalah study analitik dengan pendekatan cross sectional. Populasinya adalah seluruh siswa-siswi di SMA Kesatrian I Kota Semarang sebanyak 520 orang. Didapatkan sampel 94 responden dengan menggunakan teknik systematic random sampling. Pengumpulan data dilakukan menggunakan alat ukur kuesioner tingkat sosial ekonomi, peran keluarga, dan perilaku seksual remaja. Analisis data menggunakan analisis univariat, analisis bivariat (chi-square). Hasil penelitian didapatkan bahwa terdapat pengaruh sosial ekonomi $(p=0,025)$ dan peran keluarga $(\mathrm{p}=<0,001)$ terdapat pengaruh dalam perilaku seksual remaja di SMA Kesatrian I Kota Semarang. Oleh sebab itu pihak sekolah diharapkan untuk lebih meningkatkan komunikasi dengan para orangtua, dan mengoptimalkan kerjasama dengan lembaga pemerintahan terkait dengan pendidikan dan informasi seputar seks.
\end{abstract}

Kata kunci : Sosial Ekonomi, Peran Keluarga, Perilaku Seksual Remaja.

\begin{abstract}
[English Title: Impact Of Social Economy And Role Of Family Towards Adolescent Sexual Behavior In Kesatrian 1 High School, Semarang City] Cases of unwanted pregnancy (KTD) in 20182019 to 91 cases for Semarang City area. Socio-Economic and Family Roles are factors that influence adolescent sexual behavior. The purpose of this study was to determine the socio-economic influence and role of families on adolescent sexual behavior in Kesatrian I High School Semarang. This type of research is analytic study with cross sectional approach. The population is all students in Kesatrian I high school Semarang City of 520 people. A sample of 94 respondents was obtained using systematic random sampling technique. Data collection was carried out using socio-economic level questionnaires, family roles, and adolescent sexual behavior. Data analysis used univariate analysis, bivariate analysis (chi-square). The results showed there is an influence between socio-economic $(p=0,025)$ and family roles $(p=<0,001)$ on adolescent sexual behavior in Kesatrian I High School Semarang. Therefore, the school is expected to further improve communication with parents, and optimize cooperation with government agencies related to education and information about sex.
\end{abstract}

Keyword: Socio-Economic, Roles Family, Adolescent Sexual Behavior.

\section{Pendahuluan}

Masa remaja merupakan masa peralihan dari aseksual (masa anak-anak) menjadi seksual aktif (masa dewasa), dengan fase-fase

*) Correspondence Author (Lucky Indri Yani) E-mail: luckyindriyani5@gmail.com perkembangan seksual, remaja memiliki ketertarikan yang sangat besar terhadap seksualitas (Soetjiningsih, 2010)

Menurut Sarwono (2011) perilaku seksual adalah segala tingkah laku yang didorong oleh hasrat seksual, baik dengan lawan jenisnya 
maupun dengan sesama jenis, bentuk-bentuk perilaku seksual remaja bisa bermacam-macam, mulai dari aktivitas berpacaran (dating) sampai tingkah laku berkencan, bercumbu (necking atau petting), dan bersenggama, objek seksualnya juga bisa berupa orang lain, orang dalam khayalan ataupun diri sendiri. Akibatnya, dapat menyebabkan kehamilan yang tidak dikehendaki dan akhirnya melakukan tindakan aborsi yang tidak aman dikarenakan pasangan remaja tersebut belum siap membangun keluarga (Desmita, 2010)

Berdasarkan penelitian di berbagai kota besar di Indonesia, sekitar $72 \%$ sudah berpacaran, sekitar $92 \%$ sudah sudah pernah berciuman, Sekitar $62 \%$ sudah pernah merabaraba pasangan, sekitar $20 \%$ hingga 30\% remaja mengaku sudah pernah melakukan hubungan seks, akibatnya ancaman pola hidup seks bebas remaja secara umum tampaknya berkembang semakin serius, kelompok remaja yang masuk pada penelitian tersebut rata-rata berusia 17-21 tahun, umumnya masih bersekolah di tingkat Sekolah Menengah Atas (SMA) (Gunawan, 2011).

World Health Organization (dalam Infodatin, 2014), menyebutkan bahwa sekitar 21 juta remaja perempuan yang berumur 15-19 tahun di negara berkembang, mengalami kehamilan setiap tahun dan hampir setengah kehamilan tersebut (49\%) merupakan kehamilan yang tidak diinginkan, kehamilan tersebut salah satunya disebabkan oleh adanya seks yang dilakukan sebelum pernikahan.

Berdasarkan data yang diperoleh PILAR PKBI Jateng kasus Kehamilan Tidak Diinginkan (KTD) pada remaja yang terjadi akibat dari perilaku seksual pranikah sebanyak 64 kasus pada tahun 2013, dimana 26 kasus KTD tersebut berasal dari Kota Semarang, sedangkan jumlah kasus pada tahun 2018-2019 mengalami peningkatan, yakni menjadi 91 kasus untuk wilayah Kota Semarang sendiri. Salah satu dampak dari KTD tersebut adalah banyaknya kejadian putus sekolah dikalangan remaja sehingga menyebabkan para remaja yang nantinya akan menjadi orangtua memiliki pendidikan rendah, besar kemungkinan generasi yang ia hasilkan akan terulang seperti itu lagi (PILAR PKBI Jateng, 2019).

Menurut Soetjiningsih (2010) faktor-faktor yang mempengaruhi perilaku seksual pranikah pada remaja paling tinggi adalah hubungan antara orang tua dengan remaja, tekanan teman sebaya, pemahaman tingkat agama (religiusitas), dan eksposur media pornografi, hasil penelitian yang dilakukan menunjukkan, makin baik hubungan orang tua dengan anak remajanya, makin rendah perilaku seksual pranikah remaja.

Penelitian yang dilakukan Barus (2012) menyatakan bahwa remaja dengan status ekonomi rendah cenderung bersifat lebih agresif, karena disaat orang tua sibuk mencari uang maka anak kehilangan kesempatan untuk mendapatkan bimbingan dan pengawasan dari orang tua. Sedangkan remaja dengan status ekonomi sedang dan memiliki uang saku yang pas-pasan, bisa saja terlibat dalam kenakalan remaja termasuk melakukan perilaku seksual. Begitu juga remaja dengan status ekonomi yang berkecukupan akan lebih berpotensi untuk melakukan perilaku seksual pranikah, karena mereka relatif mudah mendapatkan segala sesuatu yang diinginkan sehingga seringkali terjerumus dalam lingkungan antisosial seperti berjudi, minum minuman keras, melakukan hubungan seksual pranikah, mengkonsumsi narkoba, dan lain sebagainya.

Berdasarkan uraian di atas maka peneliti tertarik untuk melakukan penelitian tentang apakah ada pengaruh sosial ekonomi dan peran keluarga terhadap perilaku seksual remaja di SMA Kesatrian 1 Kota Semarang.

\section{Metode}

Metode penelitian yang digunakan dalam penelitian ini bersifat study analitik dengan pendekatan cross sectional untuk mempelajari hubungan antara variabel bebas (independent) dan variabel terikat (dependent) dilakukan pengukuran dalam waktu yang sama/sesaat. Penelitian ini sosial ekonomi dan peran keluarga menjadi variabel independent (variabel bebas) dan perilaku seksual remaja menjadi variabel dependent (variabel terikat). Tujuan penelitian ini adalah untuk mengetahui pengaruh sosial ekonomi dan peran keluarga terhadap perilaku seksual remaja di SMA Kesatrian I Kota Semarang.

Lokasi penelitian ini dilakukan SMA Kesatrian I Kota Semarang, yang dilaksanakan penelitian mulai tanggal 19 September sampai 03 Oktober 2019. Populasi adalah seluruh siswasiswi SMA Kesatrian I Kota Semarang yang berjumlah 520 orang. Pengambilan sampel menggunakan teknik sampling systematic random sampling dan didapatkan sampel sebanyak 94 responden dari perhitungan rumus sebagai berikut: 


$$
\mathrm{n}=\frac{\mathrm{N}}{1+\mathrm{N}(\mathrm{e} 2)}
$$

Pengumpulan data dilakukan dengan menggunakan alat ukur kuesioner pengaruh sosial ekonomi dan peran keluarga terhadap perilaku seksual remaja. Analisis data menggunakan analisis univariat (distribusi frekuensi), analisis bivariat (chi-square).

\section{Hasil dan Pembahasan}

\section{a. Sosial Ekonomi}

Setelah dilakukan penelitian dengan cara menyebarkan kuesioner terhadap 94 responden tentang sosial ekonomi didapatkan hasil pada tabel 1 :

Tabel 1. Sosial Ekonomi

\begin{tabular}{ccc}
\hline Sosial ekonomi & $\mathbf{n}$ & $\mathbf{\%}$ \\
\hline Rendah & 7 & $7,4 \%$ \\
Sedang & 27 & $29,8 \%$ \\
Tinggi & 60 & $62,8 \%$ \\
Total & 94 & $100 \%$ \\
\hline
\end{tabular}

Berdasarkan tabel 1. Memperlihatkan dari 94 responden sebagian besar menunjukkan sosial ekonomi dalam kategori tinggi yaitu sebanyak sebanyak 60 orang $(62,8 \%)$, kemudian kategori sosial ekonomi sedang ada 27 orang $(29,8 \%)$, dan 7 orang $(7,4 \%)$ dengan sosial ekonomi rendah.

Dari hasil penelitian Barus (2012) dikatakan bahwa sosial ekonomi pada remaja dibagi menjadi 3 kategori yaitu, ekonomi tinggi, sedang, dan rendah. Sosial ekonomi remaja berpengaruh terhadap perilaku remaja itu sendiri.

\section{b. Peran Keluarga}

Setelah dilakukan penelitian dengan cara menyebarkan kuesioner tentang peran keluarga terhadap 94 responden didapatkan hasil pada tabel 2 :

Tabel 2. Peran Keluarga

\begin{tabular}{|c|c|c|}
\hline Peran Keluarga & $\mathbf{n}$ & $\%$ \\
\hline Kurang & 19 & $20,2 \%$ \\
\hline Baik & 75 & $79,8 \%$ \\
\hline Total & 94 & $100 \%$ \\
\hline
\end{tabular}

Berdasarkan tabel 2. menunjukkan mayoritas para remaja memiliki peran keluarga dalam kategori baik sebanyak 75 orang $(79,8 \%)$ dan 22 orang $(20,2 \%)$ memiliki peran keluarga dalam kurang.
Menurut Efendy (2000), peran orangtua dalam mendidik anaknya amat menentukan pembentukan karakter dan perkembangan kepribadian anak. Saluran komunikasi yang baik antara orangtua dan anaknya dapat menciptakan suasana saling memahami terhadap berbagai jenis masalah keluarga..

\section{c. Perilaku Seksual Remaja}

Setelah dilakukan penelitian dengan cara menyebarkan kuesioner terhadap 94 responden tentang peerilaku seksual remaja didapatkan hasil pada tabel 3 :

Tabel 3. Perilaku Seksual Remaja

\begin{tabular}{ccc}
\hline $\begin{array}{c}\text { Perilaku Seksual } \\
\text { Remaja }\end{array}$ & $\mathbf{n}$ & $\mathbf{\%}$ \\
\hline Ringan & 81 & $26,2 \%$ \\
Berat & 13 & $13,8 \%$ \\
Total & 94 & $100 \%$ \\
\hline
\end{tabular}

Berdasarkan tabel 3. menunjukkan mayoritas perilaku seksual pada remaja dalam kategori ringan yaitu sebanyak 77 responden (81, 9\%) memiliki perilaku seksual dalam kategori ringan dan sebanyak 17 responden $(18,1 \%)$ dalam kategori perilaku seksual berat.

Menurut Soetjiningsih (2007) pada masa ini gairah seksual remaja sudah mencapai puncak sehingga mereka mempunyai kecenderungan mempergunakan kesempatan untuk melakukan sentuhan fisik. Namun demikian, perilaku seksual mereka masih secara alamiah. Mereka tidak jarang melakukan pertemuan untuk bercumbu bahkan kadang-kadang mereka mencari kesempatan untuk melakukan hubungan seksual. Sebagian besar dari mereka mempunyai sikap yang tidak mau bertanggung jawab terhadap perilaku seksual yang mereka lakukan.

\section{d. Pengaruh Sosial Ekonomi terhadap Perilaku Seksual Remaja}

Tabel 5. Pengaruh Sosial Ekonomi terhadap Perilaku Seksual Remaja

\begin{tabular}{cccccc}
\hline \multirow{2}{*}{$\begin{array}{c}\text { Sosial } \\
\text { Ekonomi }\end{array}$} & \multicolumn{3}{c}{ Perilaku Seksual } & \multirow{2}{*}{$\boldsymbol{p}$-value } \\
\cline { 2 - 5 } & \multicolumn{2}{c}{ Ringan } & \multicolumn{2}{c}{ Berat } & \\
\cline { 2 - 5 } & $\mathbf{n}$ & $\mathbf{0}$ & $\mathbf{n}$ & $\mathbf{0}$ & \\
\hline Rendah & 4 & 4,3 & 3 & 3,2 & \\
Sedang & 26 & 27,7 & 1 & 1,1 & 0,025 \\
Berat & 51 & 54,3 & 9 & 9,6 & \\
\hline
\end{tabular}


Berdasarkan tabel 5. Menunjukkan bahwa sosial ekonomi remaja dalam kategori tinggi paling banyak melakukan perilaku seksual ringan yaitu sebanyak 51 orang $(85,0 \%)$ dan 9 orang $(13,8 \%)$ melakukan perilaku seksual berat, dengan kategori sosial ekonomi sedang juga melakukan perilaku seksual ringan sebanyak 26 orang $(96,3 \%)$ dan melakukan perilaku seksual berat hanya 1 orang $(3,7 \%)$, sedangkan untuk kategori sosial ekonomi rendah melakukan perilaku seksual ringan sebanyak 4 orang $(57,1 \%)$ dan melakukan perilaku seksual berat sebanyak 3 orang $(42,9 \%)$. Hal ini menandakan bahwa tingginya sosial ekonomi yang tinggi maka akan mempengaruhi perilaku sesual yang ada pada remaja itu sendiri.

Dari hasil kuesioner penelitian mayoritas remaja dengan sosial ekonomi tinggi akan banyak mendapat uang saku lebih sehingga lebih memiliki kesempatan untuk pergi kencan dengan lawan jenisnya, sedangkan untuk para remaja dengan staus sosial ekonomi sedang dan rendah lebih cenderung memiliki uang saku yang sedikit, sehingga hanya cukup untuk keperluan sehari-harinya saja.

Ditinjau dari uji statistic menggunakan analisis chi-square menunjukkan nilai $\mathrm{p}=0,025<$ nilai $a=0,05$. Ini berarti terdapat pengaruh sosial ekonomi terhadap perilaku seksual remaja di SMA Kesatrian 1 Kota Semarang.

Hasil ini sejalan dengan penelitian yang dilakukan oleh Farida (2016) yang menyatakan bahwa berarti semakin tinggi status sosial ekonomi maka semakin tinggi juga remaja melakukan hubungan seksual berat.

Sesuai dengan teori yang diungkapkan oleh Hurwitz (2003) menurutnya penting memperhatikan remaja yang berasal dari kondisi sosial ekonomi kelas atas. Dalam kondisi sosial ekonomi rumah tangga yang sangat tinggi, dimana remaja sudah terbiasa hidup mewah, anak-anak dengan mudah mendapatkan segala sesuatu yang membuatnya kurang menghargai dan menganggap mudah segala sesuatunya yang dapat menciptakan kehidupan berfoya-foya, sehingga anak dapat terjerumus dalam lingkungan antisosial. Kemewahan membuat anak menjadi terlalu manja, lemah secara mental, tidak mampu memanfaatkan waktu luang dengan hal-hal yang bermanfaat. Situasi demikian menyebabkan remaja menjadi agresif dan memberontak, lalu berusaha mencari kompensasi atas dirinya dengan melakukan perbuatan yang bersifat melanggar.
Penelitian yang dilakukan Wijayanti (2016) juga memberikan pendapat yang sama yaitu sosial ekonomi berpengaruh terhadap perilaku seksual pada remaja.

\section{e. Pengaruh Peran Keluarga terhadap Perilaku Seksual Remaja}

Berdasarkan Tabel 6. dapat diketahui bahwa peran keluarga yang baik paling tinggi melakukan perilaku seksual ringan yakni sebanyak 73 orang $(77,7 \%)$ yang melakukan perilaku seksual berat sebanyak 2 orang $(2,1 \%)$, untuk peran keluarga dalam kategori kurang melakukan perilaku seksual berat sebanyak 11 orang $(11,7 \%)$ dan melakukan perilaku seksual ringan sebanyak 8 orang $(8,5 \%)$. Hal ini menujukkan bahwa peran dari keluarga sangat berpengaruh dengan perilaku seksual remaja pada jaman sekarang. Dengan pengawasan yang ketat maka akan memperkecil resiko negative dari perilaku seks para remaja, Maka semakin baik peran keluarga maka semakin ringan pula perilaku seksual yang dilakukan oleh para remaja.

Tabel 6. Pengaruh Peran Keluarga terhadap Perilaku Seksual Remaja

\begin{tabular}{|c|c|c|c|c|c|}
\hline \multirow{3}{*}{$\begin{array}{c}\text { Sosial } \\
\text { Ekonomi }\end{array}$} & \multicolumn{4}{|c|}{ Perilaku Seksual } & \multirow{3}{*}{$p$-value } \\
\hline & \multicolumn{2}{|c|}{ Ringan } & \multicolumn{2}{|c|}{ Berat } & \\
\hline & $\mathbf{n}$ & $\%$ & $\mathbf{n}$ & $\%$ & \\
\hline Kurang & 8 & 8,5 & 11 & 11,7 & 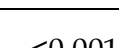 \\
\hline Baik & 73 & 77,7 & 2 & 2,1 & \\
\hline
\end{tabular}

Dari hasil kuesioner penelitian mayoritas para remaja yaang memiliki peran orang tua baik melakukan perilaku seksual ringan saja, dikarenakan para orang tua lebih dapat mengontrol pergaulan anak-anak mereka, sehingga tidak terjerumus pada pergaulan bebas.

Ditinjau dari uji statistic menggunakan analisis chi-square menunjukkan nilai $\mathrm{p}=0,00<$ nilai $a=0,05$. Ini berarti terdapat pengaruh peran keluarga terhadap perilaku seksual remaja di SMA Kesatrian 1 Kota Semarang.

Hal ini sejalan dengan penelitian yang dilakukan Maryatun (2012) pada remaja anak jalanan di kota Surakarta, dimana didapatkan hasil yang signifikan yaitu peran keluarga yang kurang berfaktor resiko 1,04 kali lebih tinggi melakukan perilaku seksual berat dibandingkan peran keluarga yang baik, dengan tingkat kepercayaan $95 \%$. 
Keluarga merupakan lingkungan pertama dan utama bagi perkembangan remaja. Umur 14 - 17 tahun dianggap sebagai titik awal proses identifikasi diri menurut jenis kelamin, peranan ibu dan ayah atau orang tua pengganti (nenek, kakek dan orang dewasa lainnya) sangat besar. Dalam mendidik, ibu dan ayah harus bersikap konsisten , terbuka, bijaksana, bersahabat, ramah, tegas, dan dapat lancar, maka dapat timbul proses identifikasi yang salah. Masa remaja merupakan pengembangan identitas diri, dimana remaja berusaha mengenal diri sendiri, ingin mengetahui bagaimana orang lain menilainya, dan mencoba menyesuaikan diri dengan harapan orang lain (Gunarsa, 2010).

Penanaman nilai-nilai budi pekerti dalam keluarga dapat dilakukan melalui keteladanan orang tua atau orang dewasa. Bacaan yang sehat , pemberian tugas, dan komunikasi efektif antar anggota keluarga. sebaliknya, apabila keluarga tidak peduli terhadap hal ini, misalnya membiarkan anak tanpa komunikasi dan memperoleh nilai diluar moral agama dan sosial, membaca buku dan menonton VCD porno, bergaul bebas, minuman keras, merokok akan berakibat buruk terhadap perkembangan jiwa remaja.

Hasil penelitian ini sejalan dengan penelitian yang dilakukan oleh Farida (2016) yang menyatakan bahwa pola asuh atau peran orang tua sangat berpengaruh terjadap perilaku seksual remaja. Orang tua yang membimbing anak remajanya untuk menjauhi perilaku seksual sebelum menikah secara terbuka dan tidak menutup-nutupinya dapat mendorong remaja untuk tidak melakukan perilaku pacaran yang merugikan.

\section{Simpulan dan Saran}

Hasil penelitian diatas dapat disimpulkan bahwa ada pengaruh sosial ekonomi terhadap perilaku seksual pada remaja dilihat dari hasil uji chi-square dengan nilai sig sebesar $0,025<$ dari nilai kritis sebesar 0,05 atau $5 \%$, dan ada pengaruh peran keluarga terhadap perilaku seksual pada remaja dilihat dari hasil uji chisquare dengan nilai sig sebesar $<0,001<$ dari nilai kritis sebesar 0,05 atau $5 \%$.

Diharapkan orang tua dapat memaksimalkan komunikasi yang baik dan nyaman dengan para remaja, agar para remaja tidak merasa sendiri dan bisa menceritakan semua masalahnya dengan keluarga, dan untuk pihak sekolah diharapkan untuk lebih meningkatkan komunikasi dengan para orangtua, dan mengoptimalkan kerjasama dengan lembaga pemerintahan terkait dengan pendidikan dan informasi seputar seks.

\section{Ucapan Terima Kasih}

Terimakasih peneliti ucapkan kepada pihak SMA Kesatrian I Kota Semarang dan Fakultas Kedokteran Prodi Sarjana Kebidanan dan Pendidikan Profesi Bidan Unissula yang telah memberikan dukungannya selama proses penelitian ini sehingga penelitian ini berjalan dengan lancar.

\section{Daftar Pustaka}

Barus, Permana Cristedi. 2012. Sosial Ekonomi Keluarga dan Hubungannya dengan Kenakalan Remaja di Desa Lantasan Baru Kecamatan Patumbak Kabupaten Deli Serdang. Universitas Sumatra Utara, Medan.

Desmita. 2010. Psikologi Perkembangan. Bandung: PT: Remaja Rosdakaraya.

Efendy, A. 2000. Perilaku Sehat, Kebiasaan Merokok dan Minuman Keras di Kalangan Remaja bali. Jakarta: PT Reneka Cipta.

Endah Ayu Sinta Dewi. 2015. Risiko Dan Refleksivitas Perilaku Seks Pranikah Pada Remaja di SMA Kesatrian 1 Kota Semarang. Thesis.

Farida Yuli. 2016. Hubungan Pengetahuan, Status Sosial Ekonomi, Pola Asuh Orang Tua, Paparan Media Pornografi Dengan Perilaku Seksual Remaja. Journal Poltekkes Bandung.

Gunarsa, S. D. 2010. Psikologi Perkembangan Anak dan Remaja. Jakarta, BPK Gunung Mulia.

Gunawan, 2011. Remaja dan Permasalahannya. Yogyakarta: Hangga Kreator.

Hurwitz S. 2003. Kriminologi. Jakarta: Bina Aksara.

Kemenkes R.I. Infodatin 2014. Jakarta.

Maryatun. 2012. Hubungan Pengetahuan dan Peran keluarga terhadap Perilaku Seksual Anak Jalanan di Surakarta.

PILAR PKBI Jateng. 2019. Remaja Butuh Akses Layanan Kesehatan Reproduksi Yang Ramah. Semarang: Divisi Layanan PILAR. 
Jurnal LINK, 16 (1), 2020, 41 - 6

DOI: 10.31983/link.v16i1.5660

Sarwono, S. 2011. Psikologi Remaja. Jakarta: PT. Raja Grafindo.

Soetjiningsih. 2007. Tumbuh Kembang Anak. Jakarta: Penerbit Buku Kedokteran.

Soetjiningsih. 2010. Tumbuh Kembang Remaja dan Permasalahannya. Jakarta: CV Sagung Seto.
Wijayanti. 2016. Hubungan antara Pengetahuan tentang Risiko Kehamilan Remaja di Luar Nikah dengan Sikap terhadap Hubungan Seksual Pra Nikah. Jurnal Kesmadaska. 